\title{
Carboxymethylcellulose and psyllium effects in sand output of horses with asymptomatic sand accumulation
}

[Efeitos da carboximetilcelulose e do psyllium sobre a eliminação de areia de cavalos com sablose assintomática]

J.M. Alonso, F.P. Schmitt, F.A.L. Sousa, G.S. Rosa, C.S. Esper, G.B. Melo Neto, M. Vettorato, J.L. Fogaça, J.C.F. Pantoja, M.J. Watanabe, A.L.G. Alves, C.A. Rodrigues, V.M.V. Machado, C.A. Hussni*

Faculdade de Medicina Veterinária e Zootecnia - Universidade Estadual Paulista - Botucatu, SP

\begin{abstract}
The aim of this study was to evaluate the effects of Psyllium (PSY) and Carboxymethylcellulose (CMC) administration on fecal elimination of sand in horses with asymptomatic sand accumulations. Eight horses were selected from sandy areas and randomly divided into 2 groups of four animals. The subjects were treated either with CMC or PSY. The presence of intestinal sand was confirmed through radiography and glove sedimentation test. The study was performed in two phases, with a 7-day interval. In phase I, all the animals received 8 liters of warm water; in phase II, the CMC group received 8 liters of water $+1 \mathrm{~g} / \mathrm{kg}$ of CMC, whereas the PSY group received 8 liters of water $+1 \mathrm{~g} / \mathrm{kg}$ of PSY. All administrations were performed through nasogastric intubation and fractionated in 2 equal volume administrations with an interval of two hours. General and specific physical examination of the digestive system were performed in conjunction with abdominal ultrasonography before the administrations and after 6, 12, 24, 36 and 48 hours, aiming to evaluate intestinal motility and presence of sand. All the feces eliminated by the animals within the 72 hours following the administrations were quantified, diluted and sedimented in order to calculate the sand output ( $\mathrm{g} / \mathrm{kg}$ of feces). All the animals were also subjected to radiographic examination to quantify sand accumulation prior to phase I and after 72 hours of phases I and II. No adverse effects were observed after the treatments. It was possible to notice higher sand elimination in both groups during the phase I, whereas no difference was observed in sand elimination rates between the groups in phase II. The radiographic scores presented differences between the initial timepoint and 72h in phases I and II for both groups. Based on the sand elimination rates and radiographic score, this study demonstrated that sand output was greater after administration of water alone, compared to CMC and Psyllium, leading to the inference that removal of the sandy environment and prevention of sand re-ingestion are effective measures for the elimination of sand from the colon of horses with asymptomatic sand accumulations.
\end{abstract}

Keywords: horses, abdominal radiography, colic, mucilage, Plantago ovata

\section{RESUMO}

O objetivo deste estudo foi avaliar os efeitos da administração do psyllium (PSY) e da carboximetilcelulose $(C M C)$ sobre a eliminação fecal de areia em equinos com sablose assintomática. Oito equinos com confirmação radiográfica de sablose assintomática foram divididos em dois grupos (grupo CMC e grupo $P S Y$ ). $O$ estudo foi realizado em duas fases, com intervalo de sete dias. Na fase 1 , todos os animais receberam $8 \mathrm{~L}$ de água; na fase 2 , o grupo CMC recebeu $8 \mathrm{~L}$ de água $+1 \mathrm{~g} / \mathrm{kg}$ de CMC e o grupo PSY recebeu $8 \mathrm{~L}$ de água $+1 \mathrm{~g} / \mathrm{kg}$ de PSY. Antes da administração de cada solução e após seis, 12, 24, 36 e 48 horas, foram realizados exame físico e ultrassonografia abdominal. Todas as fezes eliminadas em 72 horas foram avaliadas para quantificar a eliminação de areia ( $\mathrm{g} / \mathrm{kg}$ de fezes). Antes da fase 1 e após 72 horas

Recebido em 6 de junho de 2019

Aceito em 1 de outubro de 2019

*Autor para correspondência (corresponding author)

E-mail: cahussni@fmvz.unesp.br 
das fases 1 e 2, o exame radiográfico foi realizado para quantificar o escore de acúmulo de areia. Houve maior eliminação de areia após a administração de água em comparação com a administração de CMC, e não se observou diferença entre a CMC e o PSY. Uma redução significativa nos escores radiográficos de acúmulo de areia foi observada após a administração de água, bem como a manutenção dos escores após a administração da CMC e do PSY. Com base na produção de areia e no escore radiográfico, este estudo sugere que a remoção do ambiente arenoso, impedindo a reingestão de areia, é uma medida eficaz. para a eliminação da areia do cólon de cavalos com acúmulos de areia assintomáticos.

Palavras-chave: cavalos, cólica, mucilagem, Plantago ovata, radiografia abdominal

\section{INTRODUCTION}

Sand-related colic, also known as sandy enteropathy or sand impaction, is a common gastrointestinal disease in horses maintained in regions with sandy soil (Hanson, 2002; Hart et al., 2013). It may lead to decrease in performance, weight loss, intermittent and acute or chronic diarrhea, and recurrent colic (Bertone et al., 1988; Hart et al., 2013; Kaikkonem et al., 2016).

The diagnostic methods for this condition include rectal palpation (Specht and Colahan, 1988; Singer and Smith, 2002; Korolainen and Ruohoniemi, 2002), radiographic examination (Ruohoniemi et al., 2001; Korolainen and Ruohoniemi, 2002; Kendall et al., 2008; Keppie et al., 2008; Butler et al., 2017), abdominal auscultation (Ragle et al., 1989), ultrasonography (Hassel, 2002; Korolainen and Ruohoniemi, 2002) and evaluation of the presence of sand in feces (Bertone et al.,1988; Edens and Cargile, 1997; Gonçalves et al., 2005; Kendall et al., 2008). Radiographic examination is a viable alternative to locate and quantify sand in the colon of horses with symptomatic or asymptomatic sand accumulations (Ruohoniemi et al., 2001, Kendall et al., 2008).

The treatment is based on the use of fecal mass forming agents, such as Psyllium (PSY) and Carboxymethylcellulose (CMC), associated with emollient agents, osmotic laxatives and / or surfactants (Edens and Cargile, 1997; Hammock et al., 1998; Ruohoniemi et al., 2001). Psyllium is the most frequently used agent to treat sand impactions. Its administration promotes sand adhesion to the viscous solution and also lubricates the intestinal mucosa (Hammock et al., 1998; Hotwagner and Iben, 2008; Kaikkonem et al., 2016).

The CMC has a mechanism of action similar to the Psyllium, even though there are rare reports of the use of CMC in cases of sand impaction (Thomassian, 2000; Ferreira et al., 2009). The recommended doses of Psyllium and CMC can vary from $1 \mathrm{~g} / \mathrm{kg}$ (Thomassian, 2000; Ruhoniemi et al., 2001, Kaikkonem et al., 2016) to $1.3 \mathrm{~g} / \mathrm{kg}$ (Ragle et al., 1989). The aim of this study was to evaluate the effects of oral administration of Psyllium and CMC on the sand output in horses with asymptomatic sand accumulation.

\section{MATERIAL AND METHODS}

This study was approved by the ethics committee on the use of animals under protocol number $38 / 2018$. Eight male horses with mean age of $5.2 \pm 2.3$ years and mean weight of $340 \pm 52 \mathrm{~kg}$ were used to perform this study. All animals were selected from sandy areas and local reports of colic by sand impaction in other horses. The inclusion criterion was positive sand sedimentation in glove test associated with radiographic confirmation of asymptomatic sand accumulation, without previous history of colic.

The selected animals were removed from the sandy environment and kept in individual stalls, received coast cross grass hay and water ad libitum. An adaptation period of seven days was carried out before the beginning of the study. The study was divided in two phases, respecting an interval of 7 days between each one. In phase I all the animals received 8 liters of warm water $\left(38^{\circ} \mathrm{C}\right)$. The animals were randomly divided in two groups of four animals, named Carboxymethylcellulose (CMC) group and Psyllium (PSY) group.

In phase II, the CMC Group received 8 liters of warm water associated to $1 \mathrm{~g} / \mathrm{kg}$ of CMC (Chemco, Brazil), whereas the PSY Group received 8 liters of warm water associated to $1 \mathrm{~g} / \mathrm{kg}$ of Psyllium (Nutrissim, Food ingredients, Brazil). Administrations were performed through nasogastric intubation and equally fractionated 
into two administrations with a two hour interval. Given the high viscosity of the solutions, both CMC and Psyllium were administered immediately after dilution with the help of a pump (Nasco Farm \& Ranch, EUA). The horses were fasted for 12 hours prior to the administrations. No water restriction was applied.

Before the administration and after $6,12,24,36$, 48 and 72 hours in phases I and II, all the animals were subjected to a general and specific examination of the digestive system. Abdominal ultrasonography was used to evaluate intestinal motility and to verify the presence of sand. Fecal output was evaluated considering the weight, the number of defecations and the presence of sand. The occurrence of adverse effects after administrations was monitored with general physical examination (heart and respiratory rates, mucosal coloration, capillary refill time and rectal temperature). For the specific examination of the gastrointestinal tract the abdominal cavity was divided in four quadrants (right and left ventral and dorsal). After auscultating each quadrant for 3 minutes, intestinal motility was graded based on a score system where $0=$ absence of motility; $1=$ hypomotility; $2=$ normal motility and $3=$ hypermotility. Due to the subjectivity of this parameter, it was always carried out by the same evaluator to avoid evaluation bias.

Abdominal ultrasound examination (MyLab70 Esaote, Italy) was focused on the evaluation of intestinal motility and identification of intraluminal sand. Motility was assessed in the small intestine region, through the quantification of the complete movements per minute in the duodenum region. Duodenum was chosen for this evaluation, since it has a fixed position within the abdominal cavity. The identification of intraluminal sand was performed in the sternal flexure region.

The weight of fecal output was measured, as well as defecation frequency and sand output in $\mathrm{g} / \mathrm{kg}$ of feces. Within a 72-hour period, the feces were stored and weighed every 6 hours on a digital scale (Balmak-ELP 25, Brazil). After weighing, the feces were submitted to a decantation process, being diluted in the ratio of 15 (water): 1 (feces), homogenized and kept at rest for one minute. At this time the sand was decanted on the bottom of the bucket and the supernatant was discarded. The procedure was repeated until only the sand remained in the bottom of the bucket. The sand was identified and stored for later drying in an oven $\left(150^{\circ} \mathrm{C} / 20 \mathrm{~min}\right)$ and weighing in a precision scale (SSR 600- Bel Engineering, Italy). The sand output was calculated stablishing the proportion between the final sand weight and the total weight of the feces in this period.

Abdominal radiographic examinations were performed prior to phase I and 72 hours after the initial administration of phases I and II to quantify the accumulation of sand. For this purpose, an adaptation was made in the sand accumulation score described by Korolainem and Ruohoniemi (2002) and by Kendall (2008) (Table 1) (Figure 1). Abdominal radiographic examination was performed with one or two projections of the abdominal cranioventral region. The radiographic technique consisted in the use of left-right lateral projection with focus distance of $70 \mathrm{~cm}$, directed towards the sternal region. For the execution, an ECO View Unit portable digital X-ray apparatus (orange) was used with exposure factors of $100 \mathrm{kV}$ and $20 \mathrm{mAs}$ and image receivers (chassis) of $35 \mathrm{x}$ $43 \mathrm{~cm}$ size.

Due to the restricted number of animals and the presence of variation between the animals in the initial evaluation time, statistical analysis was performed using the differences between the moments, in order to eliminate the heterogeneity effect. The data were submitted to non-parametric analysis. Wilcoxon test was used, and the significant result was considered when $\mathrm{P} \leq 0.05$. Analyses were performed through PROC FREQ (SAS Institute, Cary, NC, USA).

Table 1. Adapted score of Korolainem and Ruohoniemi (2002) and Kendall (2008) for graduation of sand accumulation in the large colon

\begin{tabular}{ccc}
\hline Score & Height $(\mathrm{cm})$ & Length $(\mathrm{cm})$ \\
\hline 1 & $\geq 0.1-3.3$ & $\geq 5$ and $<10$ \\
2 & $\geq 0.1-3.3$ & $\geq 10$ and $<15$ \\
3 & $\geq 0.1-3.3$ & $\geq 15$ \\
4 & $\geq 3.3-6.6$ & $\geq 5$ and $<10$ \\
5 & $\geq 3.3-6.6$ & $\geq 10$ and $<15$ \\
6 & $\geq 3.3-6.6$ & $\geq 15$ \\
7 & $\geq 6.6-10$ & $\geq 5$ and $<10$ \\
8 & $\geq 6.6-10$ & $\geq 10$ and $<15$ \\
9 & $\geq 6.6-10$ & $\geq 15$ \\
\hline
\end{tabular}

* Adapted from Korolainem and Ruohoniemi (2002) and Kendall (2008). In the presence of more than one accumulation the sum was used to calculate the score. 




Figure 1. A simple radiographic image of the abdomen of a horse with asymptomatic sand accumulation, demonstrating the classification of the animal according to Korolainem and Ruohoniemi (2002) and Kendall (2008) scores. Animal classified in score 2, where a= height of sand accumulation $(1.2 \mathrm{~cm})$ and $b=$ length of sand accumulation $(12 \mathrm{~cm})$.

\section{RESULTS AND DISCUSSION}

Ingestion of sand may occur intentionally or not, being frequent when feeding occurs on scarce grass, as well as when streams or dams are the water sources or when the hay is ingested on the ground in conjunction with sand (Ruohoniemi et al., 2001; Husted et al., 2005). In the present study, the selected animals were previously kept in sandy areas with feed and water supply in troughs, resulting in frequent ingestion of sand together with the hay on the ground.

No adverse effects due to the administration of $\mathrm{CMC}$ and Psyllium were observed, since physical parameters remained within the physiological range. There was no significant difference in general and specific gastrointestinal physical examination between the moments or treatments, nor signs of abdominal pain were observed following the administration of CMC or Psyllium. However, it is important to point out that the dose was divided into two administrations with an interval of two hours. This fractionation was necessary due to the difficult dilution of the dose of $1 \mathrm{~g} / \mathrm{kg}$ in a volume supported by the gastric capacity for administration in a single dose.
The dose of $1 \mathrm{~g} / \mathrm{kg}$ of Psyllium (Ruohoniemi et al., 2001, Kaikkonem et al., 2016) or CMC (Thomassian, 2000) is recommended for sand impaction treatment. At this dose, however, there is no reference about the difficulty of diluting these products prior to administration. Prior to the study, several dilution and homogenization tests were performed. No macroscopic differences were obtained using room temperature $\left(25^{\circ} \mathrm{C}\right)$ or warm water $\left(38^{\circ} \mathrm{C}\right)$. A maximum dilution of $50 \mathrm{~g}$ of CMC or Psyllium per liter of water was possible. In this sense, a great volume of water should be necessary to achieve the dose of $1 \mathrm{~g} / \mathrm{kg}$ in a single application, which could exceed the gastric physiological capacity. Additionally, after dilution the product shows a volume expansion that can result in abdominal discomfort. Bergstrom et al. (2018) reported the occurrence of gastric rupture secondary to the administration of pelleted Psyllium. In addition to the high dosage used by the cited authors $(4 \mathrm{~g} / \mathrm{kg}$, four times higher than the recommended), Psyllium was administered in pellets, which caused volume expansion within the gastric compartment due to its hygroscopic feature.

The horses in this study received the treatments in two fractioned and pre diluted oral administrations, showing no signs of abdominal pain. This result confirms the feasibility of oral administration of diluted Psyllium and CMC and also presents a safe and useful method for its administration.

There was no difference in total feces weight $(\mathrm{P}=$ 0.6666) and number of defecations $(\mathrm{P}=0.7318)$ when grouping the elimination at 72 hours (Table 2 ). However, significantly higher weights were observed in feces at moments 12, 18, 24, 30, 36 and 72 hours when the moments were evaluated separately, with higher weights at phase II (CMC and Psyllium). Corroborating this finding, the number of defecations at 24 and 36 hours was significantly higher in phase II. The greater weight of feces obtained after administration of CMC and Psyllium was expected, since the mechanism of action of these substances results in fecal mass formation (Kaikkonem et al., 2016). 
Carboxymethylcellulose and psyllium...

Table 2. Median of sand output ( $\mathrm{g} / \mathrm{kg}$ feces), number of defecations and weight of feces after $72 \mathrm{~h}$ of feces collection, in phases 1 and 2

\begin{tabular}{cccc}
\hline Phase & $\begin{array}{c}\text { Sand output } \\
\text { (g of sand/Kg of feces) }\end{array}$ & $\begin{array}{c}\text { Number of } \\
\text { defecations }\end{array}$ & Feces weight $(\mathrm{Kg})$ \\
\hline Phase 1- water $(n=8)$ & $1.438^{*}$ & 31 & 43.34 \\
Phase 2 - CMC group $(n=4)$ & $0.465^{*}$ & 29 & 45.20 \\
Phase 2 - PSY group $(n=4)$ & 0.741 & 34 & 49.92 \\
\hline
\end{tabular}
*p=0.0085

When comparing the sand output in 72 hours for each phase, a higher elimination occurred in phase I (water), compared to phase II of the CMC group $(\mathrm{P}=0.0085)$. There was no significant difference between phase I versus phase II for the PSY group $(\mathrm{P}=0.1229)$, or between the two treatments in phase $2(\mathrm{P}=0.1405)$ (Table 2). Ultrasonography allowed a numerical and non-subjective analysis of the gastrointestinal motility, providing greater reliability in the data and less interference of the evaluator. Although classified as fecal mass forming agents and peristaltic enhancement promoters (Hotwagner and Iben, 2008), neither CMC nor Psyllium resulted in increase of peristalsis, presenting no statistical difference between the moments or treatments.

Abdominal ultrasound has been shown to be an efficient tool for intestinal motility evaluation (Schumitz, 1998; Reef, 1998; Jones et al., 2003). However, it was ineffective to monitor the evolution of sand impaction, since abdominal ultrasonography can detect the presence of sand, but it does not allow the measurement of its amount. These findings corroborate the previous descriptions of Korolainen and Ruohoniemi (2002), Ruohoniemi et al. (2001), Keppie et al. (2008) and Butler et al. (2017), who emphasized the radiographic examination as the ideal tool for sand quantification.

A significantly higher sand output was observed in phase I (water) at moments 54, 66 and 72 hours. At 54 hours and 66 hours, elimination after water administration was greater than in animals receiving $\mathrm{CMC}$ solution $(\mathrm{P}=0.0297$ and $\mathrm{P}=$ 0.0243 , respectively). At 72 hours, sand output after administration of water was higher than in animals receiving $\mathrm{CMC}$ and Psyllium solution $(\mathrm{P}=0.0339)$ (Figure 2). The statistical comparison of the moments was performed based on the difference between each moment and the initial moment. Due to the limited number of animals used in this study, as well as to the variation in the amount of intestinal sand in each animal at the initial moment, this analysis was required to eliminate the bias of the heterogeneity of the samples.

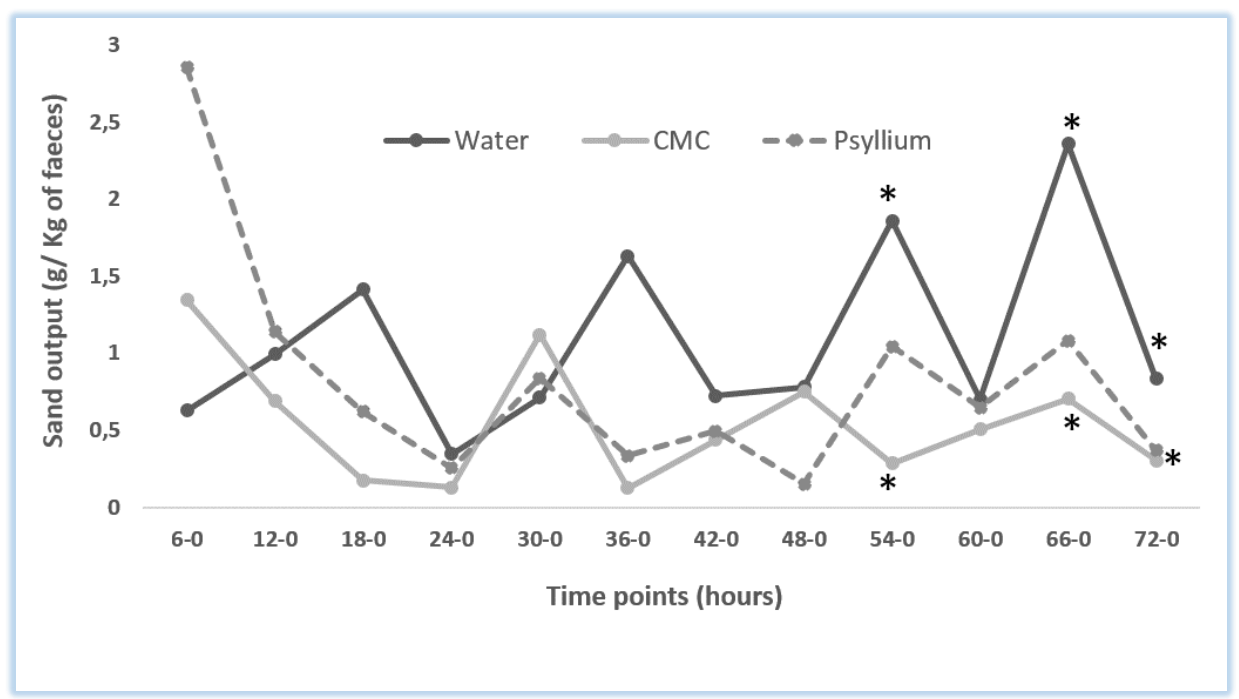

Figure 2. Sand output in study time points * Significative difference 
Between all the methods of evaluation, the measurement of the rate of sand elimination per gram of feces resulted in more reliable and objective data, even though all methods presented advantages and disadvantages. The sedimentation test and radiographic examination were less laborious procedures than sedimentation of total feces. However, sedimentation tests may present false positive or false negative results, whereas radiographic exam results in high exposure of the operators to radiation.

The sedimentation test described by Husted et al. (2005) recommend the dilution of 200 grams of feces in one liter of water in a palpation glove, evaluating the sand sedimentation and classifying the accumulation after 20 minutes in a vertical position. This test is widely used in the routine for this purpose in suspected cases of sand impaction, although it often brings false negatives, since many animals with the disease may not eliminate sand equally in all fecal samples (Kendall et al., 2008). The attempt to use the sedimentation test in the present study demonstrated an inaccuracy in this method, not only attributable to the variation of the results according to the observed glove finger, but also to the heterogeneous pattern of sand excretion over time, corroborating the results described by Kendall et al. (2008). Due to the great variation of the amount of sand eliminated between defecations, it was decided to evaluate the total excretion of sand per kilogram of feces. In order to improve the accuracy of the glove finger sedimentation test and decrease the bias of intermittent elimination, this study suggests that this analysis must be performed using serial fecal samples.
Radiographic examination is considered a good option to identify sand impaction and to monitor the treatment (Ruohoniemi et al., 2001; Korolainem and Ruohoniemi, 2002; Kendall et al., 2008; Keppie et al., 2008; Butler et al., 2017). For the complete screening of the gastrointestinal tract in the adult horse, 4 radiographic exposure windows are indicated (Rose et al., 1980). However, the structures most frequently affected by sand impaction (sternal and diaphragmatic flexures and some portions of the dorsal and ventral colons) are generally well visualized in the abdominal cranioventral region (Ruohoniemi et $a l ., 2001)$. Although the radiographic examination detected the presence of sand, a limitation was identified in the radiographic technique to detect the extent of the accumulation, which limits the achievement of the accurate scores. Such limitation occurs due to the fact that sand accumulations often exceed the limit of the chassis (Figure 3). Reef (1998) stated that the limitations of radiographic examinations in adult horses are due to the insufficient size of the radiographic films (chassis' size).

The use of two projections to the ventral abdomen, favored the understanding of the accumulations, but did not allow quantifying its extension with precision. The technique used by Kaikkonem et al. (2016), which instead of accumulation scores, the area occupied by sand is an alternative to the use of scores, but it results in the same difficulty due to the lack of information in a single projection. Ruohoneimi et al. (2001) also reported the difficulty to determine the extent of accumulation as a limiting factor of radiographic examination.
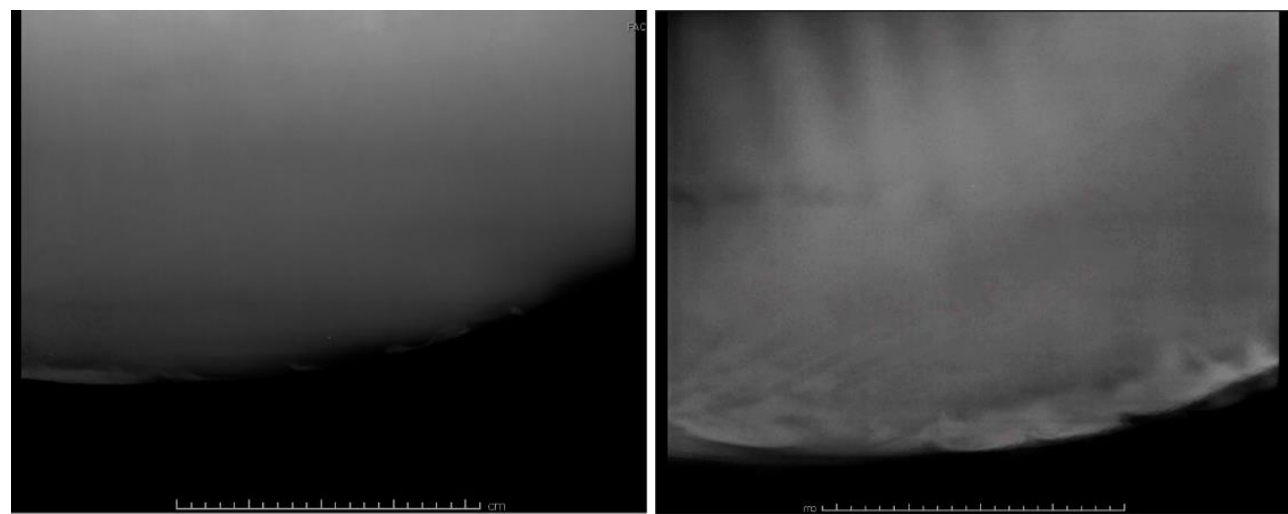

Figure 3. Examples of simple radiographic images of the abdomen of horses with asymptomatic sand accumulation, whose patterns made it difficult to establish the scores due to the presence of more than one accumulation, and/or due to the accumulation exceeding the limit of the chassis. 
In the present study, the exposure factors of 100 kilovolts $(\mathrm{kV})$ and 20 milliamperes per second (mAs) were used. This radiographic technique creates significantly lower exposure than the commonly used in the clinical routine (Weaver and Barakzai, 2010; Butler et al., 2017). The light body weight of the animals $(340 \pm 52 \mathrm{~kg})$ have facilitated the use and the success of this technique. Nevertheless, the importance of using techniques with lower radiation emission rates must always be emphasized.

Available radiographic scales for measurement of sand accumulation present a close variation on the height of the sand accumulation, making it impossible to detect significant differences in the evolution of this condition (Kendall et al., 2008). The adaptation of the scores in the present study allowed the detection of broader variations between the tests, which may also facilitate the monitoring of the evolution of the treatment in future studies and clinical cases.

The radiographic score obtained prior to administration of the solutions differed significantly from the score obtained after 72 hours of phases I and II ( $\mathrm{P}=0.0431)$. Comparing the solutions in phase I and II, there was no significant difference between the radiographic scores obtained 72 hours after administration phase $(\mathrm{P}=0.388)$ (Table 3$)$. Thus, a significant reduction of sand accumulations after water administration and maintenance of the scores after administration of CMC and PSY were demonstrated.

Table 3. Median of the radiographic score adapted from Korolainem and Ruohoniemi (2002) and Kendall (2008) for quantification of sand accumulation in the large colon prior to administration of the solutions and after 72 hours of administration in phases I and II

\begin{tabular}{cc} 
Phase & Radiographic score \\
\hline Prior to phase 1 (CMC and PSY groups) $(n=8)$ & $6^{\mathrm{A}}$ \\
Phase 1- Water (CMC and PSY groups) $(n=8)$ & $3^{\mathrm{B}}$ \\
Phase 2 - CMC group $(n=4)$ & $3^{\mathrm{B}}$ \\
Phase 2 - PSY group $(n=4)$ & $2.5^{\mathrm{B}}$ \\
\hline
\end{tabular}

*Different uppercase letters $=$ significative difference.

It is believed that Psyllium presents a greater capacity of penetration and hydration, facilitating the sand elimination when compared to other laxative substances (Edens and Cargile, 1997; Ruohoniemi et al., 2001). However, in a study conducted by Hammock et al. (1998), where sand impaction was induced and a dose of $1 \mathrm{~g} / \mathrm{kg}$ of Psyllium was administered, no improvement in sand elimination was observed. The present study also did not demonstrate greater sand elimination using CMC or Psyllium. However, it was possible to observe a greater sand elimination after exclusive administration of water when compared with the CMC solution.

In contrast, positive results were observed with the use of Psyllium by Ruohoniemi et al. (2001), who reported resolution of sand impaction after administration of Psyllium $(1 \mathrm{~g} / \mathrm{kg})$ preferably in association with mineral oil or magnesium sulfate. Landes et al. (2008) also obtained increased sand elimination after administration of a daily nutritional supplement containing a combination of prebiotic, probiotic and Psyllium in healthy horses. Hart et al. (2013) evaluated horses treated clinically with Psyllium associated with mineral oil and obtained a good prognosis in the resolution of disease. Kaikkonem et al., (2016) compared the treatment with Psyllium $(1 \mathrm{~g} / \mathrm{kg})$ associated with magnesium sulfate $(1 \mathrm{~g} / \mathrm{kg})$ to daily administration of only Psyllium (1g / kg) and observed a greater efficacy of the association with magnesium sulfate. Niinistö et al. $(2014 ; 2018)$ also obtained efficacy in sand removal when using Psyllium associated with magnesium sulfate.

Favorable results were found in most of the studies that evaluated Psyllium administered in combination with other laxatives, differently from the methodology applied in this study and also in the study published by Hammock et al. (1998), where no favorable effects of administration of fecal mass forming agents were identified. In the case of CMC, despite the indication as a sandcarrier agent (Thomassian, 2000), there are no previous studies that have evaluated its efficacy in the elimination of sand from the colon, impairing a comparison with our results. It should be emphasized that studies evaluating Psyllium alone eliminate the possibility of overlapping effects 
among the substances, making the evaluation of its properties more reliable and accurate.

The greater sand elimination demonstrated by the radiographic score and elimination rate when the horses received exclusively water suggests that the digestive system of animals that ingest sand presents a continuous, but not homogeneous, elimination rate, meaning that the removal of the animals from the sandy environment itself results in maintaining this rate of elimination. Within some days this rate achieves equilibrium due to non-re-ingestion of sand. Since in clinical practice sand impaction treatment is based on the use of fecal mass forming agents in association with osmotic laxatives and/or surfactants, and/or with emollient agents (Edens and Cargile, 1997, Hamock et al., 1998, Ruohoniemi et al., 2001), further studies are needed to verify such hypotheses and to evaluate CMC and Psyllium effect when associated with laxatives.

\section{CONCLUSION}

The results of this study indicate that sand excretion is greater after exclusive administration of water compared to CMC and Psyllium. Even though additional studies are needed to evaluate the effects of CMC and Psyllium in association with laxative agents and its use in clinical cases of symptomatic sand impaction, our data suggests that removing the animals of the sandy environment and preventing sand re-ingestion are effective measures to eliminate the sand from the colon of asymptomatic animals.

\section{REFERENCES}

BERGSTROM, T.C.; SAKAI, R.R.; NIETO, J.E. Catastrophic gastric rupture in a horse secondary to psyllium pharmacobezoars. Can. Vet. J. v.59, p.249-253, 2018.

BERTONE， J.J.; TRAUB-DARGATZ， J.L.; WRIGLEY, R.W.; BENNETT, D.G.; WILLIAMS, R.J. Diarrhea associated with sand in the gastrointestinal tract of horses. J. Am. Vet. Med. Assoc., v.193, p.1409-1412, 1988.

BUTLER, J.A.; COLLES, C.M.; DYSON, S.J.; KOLD, S.E.; POULOS, P.W. Clinical radiology of the horse. John Wiley \& Sons Inc, 2017. p.798.
EDENS, L.M.; CARGILE, J.L. Medical management of colic. In: SPRAYBERRY, K.A.; ROSISON, N.E. Current therapy in equine medicine. 4.ED. Philadelphia: Saunders, 1997. p.182-191.

FERREIRA, C.; PALHARES, M.S.; MELO, U.P.; GHELLER, V.A.; BRAGA, C.E. Cólicas por compactação em equinos: etiopatogenia, diagnóstico e tratamento. Acta Vet. Bras., v.3, p.117-126, 2009.

GONÇALVES, S.; LEBLOND, A.; DROGOUL, C.; JULLIAND, V. Using feces characteristics as a criterion for the diagnosis of colic in the horse: a clinical review of 207 cases. Rev. Med. Vet, v.157, p.3-10, 2005.

HAMMOCK, P.D.; FREEMAN, D.E.; BAKER, G.J. Failure of psyllium mucilloid to hasten evacuation of sand from the equine large intestine. Vet. Surg. v.27, p547-554, 1998.

HANSON, R.R. Sand impaction. In: MAIR, T.; Divers, T.; Ducharme, N. Manual of Equine Gastroenterology. W.B.Saunders, 2002. p 282284.

HART, K.A.; LINNENKOHL, W.; MAYER, J.R. et al. Medical management of sand enteropathy in 62 horses. Equine Vet. J., v.45, p.465-469, 2013.

HASSEL, D.M. Enterolithiasis. Clin. Tech. Equine Pract., v.1, p.143-147, 2002.

HOTWAGNER, K.; IBEN, C. Evacuation of sand from the equine intestine with mineral oil, with and without psyllium. J. Anim. Physiol. Anim. Nutr., p.92, v.86-91, 2008.

HUSTED, L.; ANDERSEN, M.S.; BORGGAARD, O.K.; HOUE, H.; OLSEN, S.N. Risk factors for faecal sand excretion in Icelandic horses. Equine Vet. J., v.37, p.351-355, 2005.

JONES, S.L.; DAVIS, J.; ROWLINGSON, K. Ultrasonographic findings in horses with right dorsal colitis: five cases (2000-2001). J. Am. Vet. Med. Assoc., v.222, p.1248-1251, 2003.

KAIKKONEN, R.; NIINISTÖ, K.; LINDHOLM, T.; RAEKALLIO, M. Comparison of psyllium feeding at home and nasogastric intubation of psyllium and magnesium sulfate in the hospital as a treatment for naturally occurring colonic sand (geosediment) accumulations in horses: a retrospective study. Acta Vet. Scand., v.58, p.73, 2016. 
KENDALL, A.; LEY, C.; EGENVALL, A.; BRÖJER, J. Radiographic parameters for diagnosing sand colic in horses. Acta Vet. Scand., v.50, p.17, 2008.

KEPPIE, N.J.; ROSENSTEIN, D.S.; HOLCOMBE, S.J.; SCHOTT, H.C. Objective radiographic assessment of abdominal sand accumulation in horses. Vet. Radiol. Ultrasound, v.49, p.122-128, 2008.

KOROLAINEN, R.; RUOHONIEMI, M. Reliability of ultrasonography compared to radiography in revealing intestinal sand accumulations in horses. Equine Vet. J., v.34, p.499-504, 2002.

LANDES, A.D.; HASSEL, D.M.; FUNK, J.D.; HILL, A. Fecal sand clearance is enhanced with a product combining probiotics, prebiotics, and psyllium in clinically normal horses. J. equine Vet. Sci., v.28, p.79-84, 2008.

NIINISTÖ, K.; HEWETSON, M.; KAIKKONEN, R.; SYKES, B.W.; RAEKALLIO, M. Comparison of the effects of enteral psyllium, magnesium sulphate and their combination for removal of sand from the large colon of horses. Vet. J., v.202, p.608-611, 2014.

NIINISTÖ, K.E.; RUOHONIEMI, M.O.; FRECCERO, F.; RAEKALLIO, M.R. Investigation of the treatment of sand accumulations in the equine large colon with psyllium and magnesium sulphate. Vet. J., v.238, p.22-26, 2018.

RAGLE, C.A.; MEAGHER, D.; SCHRADER, J.L.; HONNAS, C.M. Abdominal auscultation in the detection of experimentally induced gastrointestinal sand accumulation. J. Vet. Intern. Med., v.3, p.12-14, 1989.
REEF, V.B. Equine diagnostic ultrasound. Philadelphia: WB Saunders Company, 1998.

ROSE, J.A.; ROSE, E.M.; SANDE, R.D. Radiography in the diagnosis of equine enterolithiasis. In: PROCEEDINGS ANNUAL CONVENTION OF THE AMERICAN ASSOCIATION OF EQUINE PRACTITIONERS, 1980. Proceedings... [s.1.]: AAEP, 1980.

RUOHONIEMI, M.; KAIKKONEN, R.; RAEKALLIO, M.; LUUKKANEN, L. Abdominal radiography in monitoring the resolution of sand accumulations from the large colon of horses treated medically. Equine Vet. J., v.33, p.59-64, 2001.

SCHMITZ, D.G. Abdominal ultrasonography. In: RANTANEN, N.W.; MCKINNON, A.O. (Eds.). Equine diagnostic ultrason. Baltimore: Williams Wilkins, 1998. p.47-71.

SINGER, E.R.; SMITH, M.A. Examination of the horse with colic: is it medical or surgical? Equine Vet. Educ., v.14, p.87-96, 2002.

SPECHT, T.E.; COLAHAN, P.T. Surgical treatment of sand colic in equids: 48 cases (19781985). J. Am. Vet. Med. Assoc., p.193, p.15601564, 1988.

THOMASSIAN, A. Restabelecimento do trânsito intestinal em eqüinos. Parte II: tratamento. Rev. Educ. Contin. Med. Vet. Zootec. CRMV-SP, v.3, p.14-23, 2000.

WEAVER, M.; BARAKZAI, S. Handbook of equine radiography. Edinburgh: Saunders/ Elsevier, 2010. 183p. 